\title{
Sayuran Organik Sistem Vertikultur Aquaponik Sebagai Pemanfaatan Lahan Pekarangan
}

\author{
Nur Prihatiningsih ${ }^{1}{ }^{*}$, Endang Warih Minarni ${ }^{1}$, Nurtiati ${ }^{1}$ \\ ${ }^{1}$ Fakultas Pertanian, Universitas Jenderal Soedirman, Purwokerto, Indonesia \\ *Penulis korespondensi, email: nur.prihatiningsih@unsoed.ac.id
}

\section{Submit : \\ 8 Juli 2020 \\ Diterima: \\ 18 Agustus 2020 \\ Terbit:}

20 Agustus 2020
Abstrak. Kesadaran masyarakat akan keamanan pangan dan gizi
menyebabkan masyarakat memberikan perhatian lebih besar
pada kualitas dan keamanan produk sayuran yang dikonsumsi dan
menginginkan makanan yang serba alami dan bebas dari bahan
kimia, baik dari pestisida, hormon dan pupuk. Permasalahan mitra
adalah belum mengetahui paket teknologi budidaya sayuran
secara ramah lingkungan, baik dari segi ekonomi, kesehatan, dan
keamanan pangan yang dapat diterapkan untuk memanfaatkan
pekarangan secara vertikultur aquaponik. Untuk mengatasi
permasalahan mitra beberapa solusi teknologi yang ditawarkan adalah transfer teknologi melalui pendampingan, pendidikan, dan demplot. Tujuan kegiatan ini adalah memanfaatkan lahan pekarangan di sekitar pemukiman dengan menanam tanaman sayuran ramah lingkungan dengan teknologi vertikultur aquaponik dan aplikasi basubio sebagai pengendali hayati dan pupuk hayati. Metode ceramah dan diskusi dilakukan sebagai media alih informasi yang bersifat interaktif dan berlangsung dua arah. Metode ini merupakan inisiasi program dengan harapan, kelompok mitra mempunyai pengetahuan dasar yang baik tentang pengetahuan budidaya tanaman sayuran secara vertikultur aquaponik, memanfaatkan lahan kosong di sekitar rumah mereka, sehingga tercipta lingkungan yang nyaman, dan hasil panennya dapat dikonsumsi secara aman. Penerapan program dilanjutkan dengan peningkatan ketrampilan anggota kelompok Dasawisma melalui pelatihan dilengkapi dengan demplot. Hasil kegiatan yang dilakukan antara lain: budidaya sayuran secara vertikultur aquaponik yang ramah lingkungan. Pembuatan biofertilizer dan biopestisida berbahan aktif $B$. subtilis, pembuatan MOL (mikroorganisme lokal) dan pestisida nabati untuk mendukung kesehatan dan keamanan pangan. Dampak dari kegiatan ini menambah pengetahuan dan ketrampilan kelompok Dasawisma mencapai $95 \%$ dan menambah indah lingkungan dan hasil sayurannya dapat dimanfaatkan dalam kebutuhan makan seharihari.

Kata Kunci: aquaponik, lahan pekarangan, tanaman sayuran, vertikultur 


\section{PENDAHULUAN}

Pasir Kulon adalah sebuah desa yang terletak di Timur Utara Kecamatan Karanglewas, Kabupaten Banyumas, Jawa Tengah, yang dilalui oleh sebuah jalan raya, yaitu Jl. Sunan Bonang yang merupakan nama salah satu sunan dari sembilan wali (Jawa: Wali Songo) yang diabadikan menjadi sebuah jalan. Budidaya tanaman sayuran di lahan Desa Pasir Kulon, Kecamatan Karanglewas, Kabupaten Banyumas masih secara konvensional. Luas wilayah Desa Pasir Kulon 149 $\mathrm{km}^{2}$, terletak di bagian barat wilayah Kabupaten Banyumas dengan jarak 8 $\mathrm{km}$ dari ibukota kabupaten dan terletak di bagian barat wilayah Kecamatan Purwokerto Barat dengan jarak $4 \mathrm{~km}$ dari ibukota kecamatan, dan 10 km dari kampus Unsoed.

Lahan pertanian di kelurahan Pasir Kulon potensial untuk pengembangan tanaman padi, palawija dan hortikultura. Cabai terung, selada dan tomat merupakan produk tanaman sayuran, yang mempunyai potensi penting untuk dikembangkan. Luas tanaman sayuran seperti cabai, terung, kacang panjang dan tomat mencapai 2 ha di Pasir Kulon dengan produksi rata-rata 5 ton/ha. Pada tahun mendatang pengembangan pertanaman selada, cabai, tomat dan terung akan meningkat seiring dengan kebutuhan dan kesadaran masyarakat tentang gizi. (Dinas Kesejahteraan Sosial dan Pemberdayaan Masyarakat, 2005). Tingkat perkembangan Pasir Kulon termasuk maju, terbukti dengan antusias warga dan perangkat desa pada kegiatan lain sebelumnya yang menghendaki adanya keberlanjutan dan kesinambungan kegiatan serta evaluasi yang nyata. Oleh karena itu perlu dilakukan penerapan alih teknologi di desa tersebut untuk menjembatani perkembangan teknologi dan pemberdayaan masyarakat serta potensi desa.

Pertanian yang ramah lingkungan kini didambakan oleh masyarakat, karena akan tercipta lingkungan yang nyaman, sehat dan terjaga keamanan pangan. Untuk menciptakan situasi yang demikian diperlukan inovasi teknologi dengan memanfaatkan bahan alami seperti mikroba berguna yang dapat berfungsi sebagai biofertilizer dan biopestisida. Pemanfaatan pekarangan dengan tanaman sayuran organik secara vertikultur dan aquaponik selain mampu sebagai pemenuhan kebutuhan sayuran sehat juga mempunyai nilai estetika, sehingga menghasilkan tanaman yang aman dikonsumsi dan memberi kenyamanan bagi lingkungan. Sejalan dengan perkembangan ilmu pengetahuan dan teknologi, banyak penemuan baru yang kemudian menggeser sistem pertanian tradisional menjadi sistem pertanian konvensional. Sistem pertanian konvensional dicirikan dengan penggunaan input anorganik dan bahan kimia pertanian dalam proses budidaya. Hal ini ternyata membawa dampak negatif, akibatnya adalah timbulnya masalah baru dalam pertanian sayuran, yaitu pencemaran air oleh bahan kimia, menurunnya kualitas dan produktivitas sayuran, ketergantungan terhadap bahan kimia pertanian seperti pupuk dan pestisida serta merosotnya produktivitas lahan karena erosi, pemadatan lahan dan kurangnya bahan organik (Aktar et al., 2009). Dampak lain yang ditimbulkan oleh pertanian konvensional adalah gangguan kesehatan yang diakibatkan adanya residu kimia yang terkandung dalam produk sayuran (Kumar, 2012).

Melalui aplikasi MOL (mikroorganisme lokal), pestisida nabati dan biopestisida berbasis $B$. subtilis ini dapat mengurangi penggunaan bahan kimia sintetik (Prihatiningsih et al., 2011). Biopestisida ini pernah digunakan untuk mengendalikan penyakit hawar daun kentang. layu bakteri pada tanaman kentang, tomat dan cabai (Mugiastuti dan Prihatiningsih, 2011; Prihatiningsih et al., 2013). Selain itu dengan $B$. 
subtilis B46 yang dikombinasi dengan Streptomyces S4 dalam formula biopestisida dapat untuk mengendalikan penyakit lincat pada tembakau (Prihatiningsih et al., 2010).

\section{METODE}

Materi dalam kegiatan ini adalah benih dan bibit tanaman sayuran, kangkung, selada, seledri, muncang, caisin, cabai, tomat, pakcoy. Media tanam menggunakan tanah, sekam dan pupuk kandang $(1: 1: 1)$, sebagai media tumbuh dan biopestisida digunakan BASUBIO yang diaplikasikan dengan cara disiram/dikocor di sekitar lubang tanam.

Metode yang dilaksanakan dalam kegiatan pengabdian ini adalah: 1) Alih Teknologi atau alih pengetahuan dilakukan dengan cara meningkatkan pengetahuan petani melalui ceramah dan diskusi, pelatihan pembuatan dan aplikasi biopestisida berbasis $B$. subtilis B298, sehingga peserta dapat berperan secara aktif, 2) Demonstrasi plot (demplot), peningkatan ketrampilan mitra dalam budidaya sayuran organik secara vertikultur aquaponik. Demplot yang dilaksanakan adalah budidaya tanaman sayuran organik dan cara aplikasi MOL, pesnab dan biopestisida berbasis $B$. subtilis. Partisipasi mitra dalam pelaksanaan program adalah menyediakan anggota kelompok sebagai khalayak sasaran dalam pelaksanaan program KKN PPM dan menyediakan lahan untuk demplot atau percontohan.

Evaluasi kegiatan pengabdian pada program KKN PPM ini dievaluasi berdasarkan pengukuran perubahan sikap atau kebiasaan dan kesungguhan dalam melaksanakan kegiatan.

\section{Pengukuran perubahan sikap atau kebiasaan}

Ada tiga macam parameter yang diukur pada evaluasi cara ini, yaitu pengetahuan, sikap, dan ketrampilan (Mardikanto, 1992).

a. Parameter pengetahuan dan sikap, diukur dengan cara melakukan pre dan post test dengan mengisi jawaban dari pertanyaan. Cara mengisi jawaban dengan memilih alternatif yang dianggap tepat, yaitu Skor 1: tidak setuju; 2: kurang setuju; 3 : setuju.

Penilaian peningkatan pengetahuan menggunakan rumus sebagai berikut: $\mathrm{PP}=\mathrm{n} \mathrm{Po}-\mathrm{n} \mathrm{Pr}$

$\mathrm{PP}$ : peningkatan pengetahuan

n Po: nilai post test

n Pr: nilai pre test

Semakin besar nilai PP, menunjukkan semakin meningkatnya pengetahuan.

b. Parameter ketrampilan, diukur berdasarkan pengamatan dengan pemberian skor tertentu dari alternatif hasil pengamatan terhadap proses atau hasil kegiatan aplikasi biopestisida dengan hasil akhir aplikasi berupa pengamatan pertumbuhan dan hasil tanaman.

\section{HASIL DAN PEMBAHASAN}

Kegiatan pengabdian kepada masyarakat telah dilaksanakan dengan partisipasi dan antusias peserta. Hal ini ditunjukkan dengan kenaikan nilai post test dibandingkan dengan nilai pretest. Hasil kegiatan berupa penyuluhan dan pelatihan serta demplot pemanfaatan lahan di sekitar perumahan dengan penanaman tanaman sayuran secara vertikultur aquaponik dan dengan polibag menambah pengetahuan dan ketrampilan anggota kelompok masyarakat dan menambah keindahan lingkungan. Hasil pelaksanaan kegiatan dapat dilihat pada Tabel 1.

Berdasarkan hasil perhitungan rerata terjadi peningkatan pengetahuan di tingkat kelompok Dasawisma Desa Pasir Kulon Kecamatan Karanglewas Kabupaten Banyumas. Hal ini terlaksana atas partisipasi aktif dari anggota kelompok tersebut, perangkat desa dan semangat mahasiswa KKN dan tim pengabdi 
serta respon positif yang diterima. Kondisi lahan pekarangan setelah pelaksanaan kegiatan pengabdian dapat dilihat pada Gambar 1.

Tabel 1. Pengetahuan kelompok Dasawisma tentang pemanfaatan lahan dengan tanaman sayuran ramah lingkungan di Desa Pasir Kulon

\begin{tabular}{|c|c|c|}
\hline Jenis Pertanyaan & $\begin{array}{l}\text { Nilai } \\
\text { Pre } \\
\text { Test } \\
(\%)\end{array}$ & $\begin{array}{l}\text { Nilai } \\
\text { Post } \\
\text { Test } \\
(\%)\end{array}$ \\
\hline $\begin{array}{l}\text { Pengetahuan tentang } \\
\text { tanaman sayuran } \\
\text { ramah lingkungan }\end{array}$ & 65.6 & 96,7 \\
\hline $\begin{array}{l}\text { Pengetahuan tentang } \\
\text { vertikultur aquaponik }\end{array}$ & 68,7 & 92,3 \\
\hline $\begin{array}{l}\text { Cara aplikasi MOL, } \\
\text { pesnab, Biopestisida } \\
\text { B. subtilis B298 }\end{array}$ & 54,2 & 95,8 \\
\hline $\begin{array}{l}\text { Penilaian tanaman } \\
\text { sehat }\end{array}$ & 65,8 & 96,2 \\
\hline $\begin{array}{l}\text { Evaluasi hasil } \\
\text { kegiatan setelah } \\
\text { aplikasi MOL, Pesnab, } \\
\text { Biopestisida }\end{array}$ & 62.8 & 88.9 \\
\hline
\end{tabular}
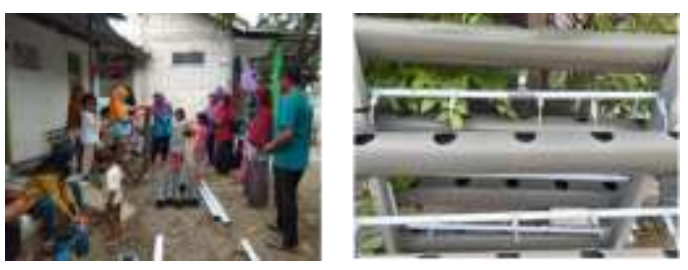

Gambar 1. Penyiapan pembuatan rak vertikultur dan penanaman tanaman sayuran secara vertikultur

Berdasarkan hasil penanaman tanaman sayuran dengan cara vertikultur, menambah semangat ibuibu untuk memanfaatkan sebagian sisa tanahnya di sekitar rumahnya untuk menanam tanaman sayuran. Hasil dari kegiatan dengan cara vertikultur dapat dilihat pada Gambar 2 , yang menunjukkan sayuran selada, kangkung, seledri dan daun bawang bersih serta ramah lingkungan karena tidak menggunakan pestisida sintetik sehingga aman untuk dikonsumsi. Antusias warga nampak pada pelaksanaan dan saat melihat hasilnya, mereka berkeinginan agar kegiatan ini berlanjut selain untuk memanfaatkan lahan juga menambah nilai gizi yang murah dan lingkungan menjadi tampak asri.

Selain penanaman secara vertikultur aquaponik juga dilakukan dengan vertikultur irigasi tetes untuk menambah pengetahuan, ketrampilan dan keindahan lingkungan. Sebelumnya dilakukan penyuluhan tentang manfaat tanaman sayuran sebagai pengisi lahan kosong dan pengetahuan tentang organisme pengganggu tanaman sayuran serta upaya untuk mengendalikannya. Hasil yang terukur dari kegiatan ini adalah peningkatan pengetahuan dan ketrampilan serta tingkat keindahan dari lahan sekitar pemukiman.

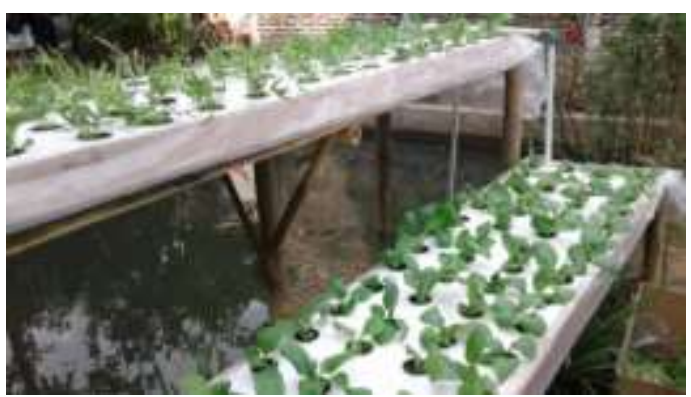

Gambar 2. Pemanfaatan kolam ikan sebagai vertikultur aquaponik

Pembuatan MOL, pestisida nabati dan biopestisida berbasis Bacillus subtilis dapat dilihat pada Gambar 3. Hasil panen sesuai dengan perkiraan dari jumlah tanaman yang ditanam 90\% dapat sampai panen dan yang $10 \%$ rusak baik disebabkan oleh ayam. Hasil panen dikemas supaya lebih menarik dan punya nilai jual dapat dilihat pada Gambar 4.
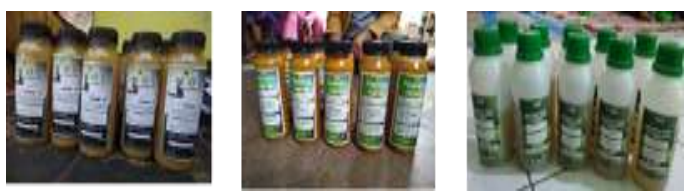

Gambar 3. Pembuatan MOL, Pestisida Nabati dan Biopestisida Basubio 


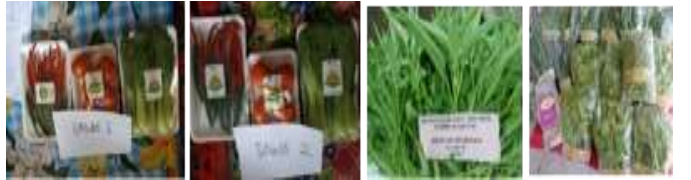

Gambar 4. Teknik pengemasan dari hasil panen tanaman sayuran yang ditanam secara vertikultur-aquaponik

\section{KESIMPULAN}

Berdasarkan hasil pelaksanaan kegiatan KKN-PPM maka dapat diambil kesimpulan sebagai berikut:

1. Pelaksanaan kegiatan KKN-PPM di Desa Pasir Kulon berjalan lancar atas peran aktif anggota kelompok Dasawisma, aparat desa dan aktivitas tim KKN-PPM

2. Anggota kelompok Dasawisma aktif dan responsif menerima teknologi baru pemanfaatan lahan pekarangan dengan tanaman sayuran yang ramah lingkungan dengan teknik vertikulturaquaponik dan merasa antusias akan keberlanjutan program ini beserta pendampingan evaluasinya.

3. Hasil penanaman secara vertikultur aquaponik dan pada polibag menunjukkan contoh aplikasi MOL, pesnab dan biopestisida berbasis $B$. subtilis B298, yang mampu meningkatkan hasil tanaman sayuran organik.

\section{UCAPAN TERIMAKASIH}

Terima kasih disampaikan kepada Kementerian Riset, Teknologi, dan Pendidikan Tinggi yang telah memberi dana guna mendukung kegiatan KKNPPM 2019.

\section{DAFTAR PUSTAKA}

Aktar MW, Sengupta D, Chowdhury A. 2009. Impact of pesticides use in agriculture: their benefits and hazards. Interdiciplinary Toxicology 2(1): 1-12

Dinas Kesejahteraan Sosial dan Pemberdayaan Masyarakat. 2005. Daftar Isian Potensi Desa (Desa Banteran Kecamatan Sumbang Kabupaten Banyumas). 20 hal.
Hisyam A M. 2007. Pengaruh Konsentrasi dan Frekuensi Pemberian POC terhadap Pertumbuhan dan Hasil Tanaman Caisim (Brassica chinensis). Skripsi. Fakultas Pertanian. Universitas Jenderal Soedirman, Purwokerto. Tidak dipublikasikan.

Kumar S. 2012. Biopesticides: A need for Food and Environmental Safety. Journal of biofertilizer biopesticide: 3: 2-4

Mardikanto T. 1992. Penyuluhan Pembangunan Pertanian. Sebelas Maret University Press. Solo.

Mugiastuti E, Prihatiningsih N. 2011. Pemanfaatan Bacillus sp. untuk pengendalian penyakit hawar daun kentang. Jurnal Pembangunan Pedesaan 11(2): 95-101

Prihatiningsih $\mathrm{N}$, Djatmiko $\mathrm{HA}$, Arwiyanto T. 2013. Pengendalian Ralstonia solanacearum kentang dengan Bacillus subtilis B315. Makalah Seminar Nasional "Pengembangan sumber daya pedesaan dan kearifan lokal berkelanjutan III" di LPPM Unsoed.

Prihatiningsih N, Djatmiko HA, Rochminarsi E. 2011. Applications of potassium fertilizer and Bacillus sp. biopesticide for increasing tomato resistance to bacterial wilt disease. Agrivita 33(1): 914

Prihatiningsih N, Djatmiko HA, Herminanto. 2010. Potensi Bacillus spp. B46 dan Streptomyces spp. S4 sebagai agens pengendali penyebab penyakit lincat pada tembakau. Agronomika 10(2): 43-55

Wangsit St, Supriyana D. 2003. Belajar dari Petani. Kumpulan Pengalaman Bertani Organik. SPTN-HPS-Lesman-Mitra Tani, Yogjakarta. 214 hal 